\title{
Patterns of higher taxon colonisation and development in sessile marine benthic assemblages at Casey Station, Antarctica, and their use in environmental monitoring
}

\author{
Jonathan S. Stark* \\ Australian Antarctic Division, Channel Highway, Kingston, Tasmania 7050, Australia
}

\begin{abstract}
Colonisation and development of sessile epibiotic assemblages on tiles was studied at Casey Station, East Antarctica, using a mix of higher taxon classifications (family to phylum). Tiles were deployed for 1 and 3 yr at 3 control and 2 impacted locations. Assemblages on upper and lower surfaces of tiles were very different, with little colonisation of upper surfaces ( 0 to $11 \%$ after 3 yr) and extensive colonisation of lower surfaces (60 to $91 \%$ after $3 \mathrm{yr}$ ), which is greater than previously reported from Antarctica. Hypotheses were tested relating to spatial variation, depth, human impacts (a sewage outfall and a waste disposal site) and period of deployment. Differences between control locations were only apparent after $3 \mathrm{yr}$, but there were significant differences between control and impacted locations after $1 \mathrm{yr}$. There were differences between assemblages at 7 to $10 \mathrm{~m}$ and 19 to $22 \mathrm{~m}$. Assemblages were initially dominated by spirorbid polychaetes and bryozoans, but by 3 yr there was significant sponge cover at some locations. Both impacted locations had significantly greater cover on upper surfaces than controls. The waste disposal site had the least cover on lower surfaces, with almost no sponge and less bryozoans than controls. The outfall had the greatest cover on the lower surfaces, the greatest cover of spirorbids and sponges but the least cover of bryozoans. Higher taxa assemblage patterns of colonisation on settlement panels are potentially useful as a medium- to long-term monitoring tool for sheltered Antarctic nearshore waters.
\end{abstract}

KEY WORDS: Marine benthos - Colonisation · Settlement panels - Environmental impact . Assemblage succession · Monitoring

\section{INTRODUCTION}

Settlement panels provide an ideal tool for investigating ecological patterns and processes of sessile encrusting epifauna in benthic ecosystems (e.g. Stachowicz et al. 2002). They have been used to study environmental impacts in temperate environments, for example of marinas (Glasby 1997, 1998), and the role of urban structures as marine habitats (Connell 2001). They reduce heterogeneity associated with natural substrata, provide a degree of uniformity and facilitate replication, which is essential to estimate natural variation in comparisons of different areas. Studies of developing epibiotic assemblages in temperate areas have found significant spatial variation at scales from 10s to 1000s of m (Keough 1983, Butler 1986, Glasby 1998), but settlement panels are also suitable in tests for differences and patterns at local scales (Glasby 1998), making them useful in impact assessment and monitoring.

Environmental impact studies in near-shore habitats commonly focus on assemblages of soft-sediment macrofauna, largely because sediments accumulate contaminants (Goldberg et al. 1975, Stark et al. 2003b). Less common is the use of assemblages on hard substrata, which provide different ecological information, as they are less likely to be affected by accumulated contaminants in sediments. Their development is more responsive to short-term or periodic environmental changes, such as waterborne pulsed pollution events, 
which may occur when contaminants are introduced or resuspended. The few previous studies of epibiotic assemblage development on hard substratum in Antarctica have reported very low colonisation rates (Dayton 1989, Rauschert 1991, Barnes 1996, StanwellSmith \& Barnes 1997). Recently, however, Bowden et al. (2006) reported faster colonisation rates in Antarctica with assemblage development that was highly location-specific in terms of both composition and abundance, with significant spatial variability at scales of $<5 \mathrm{~km}$, and also influenced by depth.

There is a need for techniques suitable for monitoring the impact of anthropogenic activities like sewage release and waste disposal on the Antarctic environment. Antarctic stations established before the late 1980s disposed of waste in convenient landfill sites, often close to shorelines. Abandoned waste disposal sites pose environmental threats to marine ecosystems through runoff and leaching of contaminants into the sea during summer melt periods, creating pulsed pollution events. The effects of these waste disposal sites has become a recent focus of research in areas of Antarctica (Lenihan 1992, Lenihan \& Oliver 1995, Stark et al. 2003a,b, 2004, 2005), but this research has focused exclusively on soft sediments. There has also been research into the effects of sewage outfalls on soft sediments in Antarctica (Green \& Nichols 1995, Conlan et al. 2004). Research at Casey Station has shown conclusive evidence of environmental impacts of a waste disposal site and the sewage outfall in soft sediments (Stark et al. 2003a,b, 2004). However, there are no published studies of environmental impacts on benthic assemblages in hard substratum habitats in Antarctica, and settlement panels have not been used there for environmental monitoring or impact assessment.

Fauna in soft sediments exhibit a range of responses to certain types of stressors, some of which can be characterised at higher taxonomic levels, e.g. polychaetes and organic contamination (Pearson \& Rosenberg 1978). Despite species-level differences within a taxon in response to environmental influences, it has been clearly demonstrated that there are generalized higher-level taxon responses to certain stressors (such as pollution), some of which are apparent even at the phylum level (Lenihan et al. 2003). These higher-taxon responses are generally driven by particular species or families within the taxon, for which there may be contrasting responses for other species or families within the same taxon (Lenihan et al. 2003). This does not invalidate the higher-taxon pattern that is observed in response to a stressor. Whether the actual cause is direct (e.g. sensitivity to pollution) or indirect (e.g. a release from predation), such characteristic patterns can be valuable, e.g. in a monitoring context. These quantitative observations not only provide the context and basis for further understanding of the mechanisms and processes responsible (Underwood et al. 2000), but also provide important information in their own right. Many studies have demonstrated little loss of information by analysing data at higher taxonomic levels, even phylum (Warwick 1988, Somerfield \& Clarke 1995, Olsgard et al. 1998), but even where species level patterns may be different, important information can be gained at higher levels. Working at higher levels may also reduced the noise and variability associated with signals at species level (Warwick 1993). Additionally, the concept of identifying organisms to a level sufficient to meet a study's objectives, such as for environmental monitoring, or to streamline sample processing is well known (Ellis 1985, Anderson et al. 2005). Responses of biota on hard substrata to pollution at higher taxononomic levels are less well known than in sediments, but they have been shown to exhibit clear patterns in response to other environmental variables from family level, e.g. spirorbid polychaetes (Glasby \& Connell 2001), up to phylum level, e.g. sponges (Glasby 2001). While species identifications are important to certain ecological questions, the extent to which assemblage patterns at higher taxonomic levels relate to environmental influences warrants further investigation (Anderson et al. 2005).

The aim of this study was to determine whether there were general patterns of colonisation and development of Antarctic sessile benthic assemblages apparent at higher taxonomic levels, using coarse resolution of family, morphospecies/functional groups and phylum and to determine how useful these might be for environmental monitoring. Five hypotheses were tested relating to assemblage development on tiles: (1) spatial—that there would be differences in assemblages at scales of several $\mathrm{km}$ (between locations), and at 10 to $50 \mathrm{~m}$ (between sites within locations); (2) impact-that there would be differences between impacted locations (adjacent to a waste disposal site and a sewage outfall) and control locations; (3) depth - that there would be differences between depths within locations; (4) temporal-that there would be differences between assemblages at 1 and 3 $\mathrm{yr}_{\text {; }}$ and (5) variability - that there would be differences in the variability of assemblages between control and impacted locations.

\section{MATERIALS AND METHODS}

Study area. Casey Station $\left(66^{\circ} 17^{\prime} \mathrm{S}, 110^{\circ} 32^{\prime} \mathrm{E}\right)$ is in the Windmill Islands, East Antarctica (Fig. 1a,b). Low rocky hills and ice cliffs border several bays around Casey, which contain smaller, inner bays. Sea ice cover 


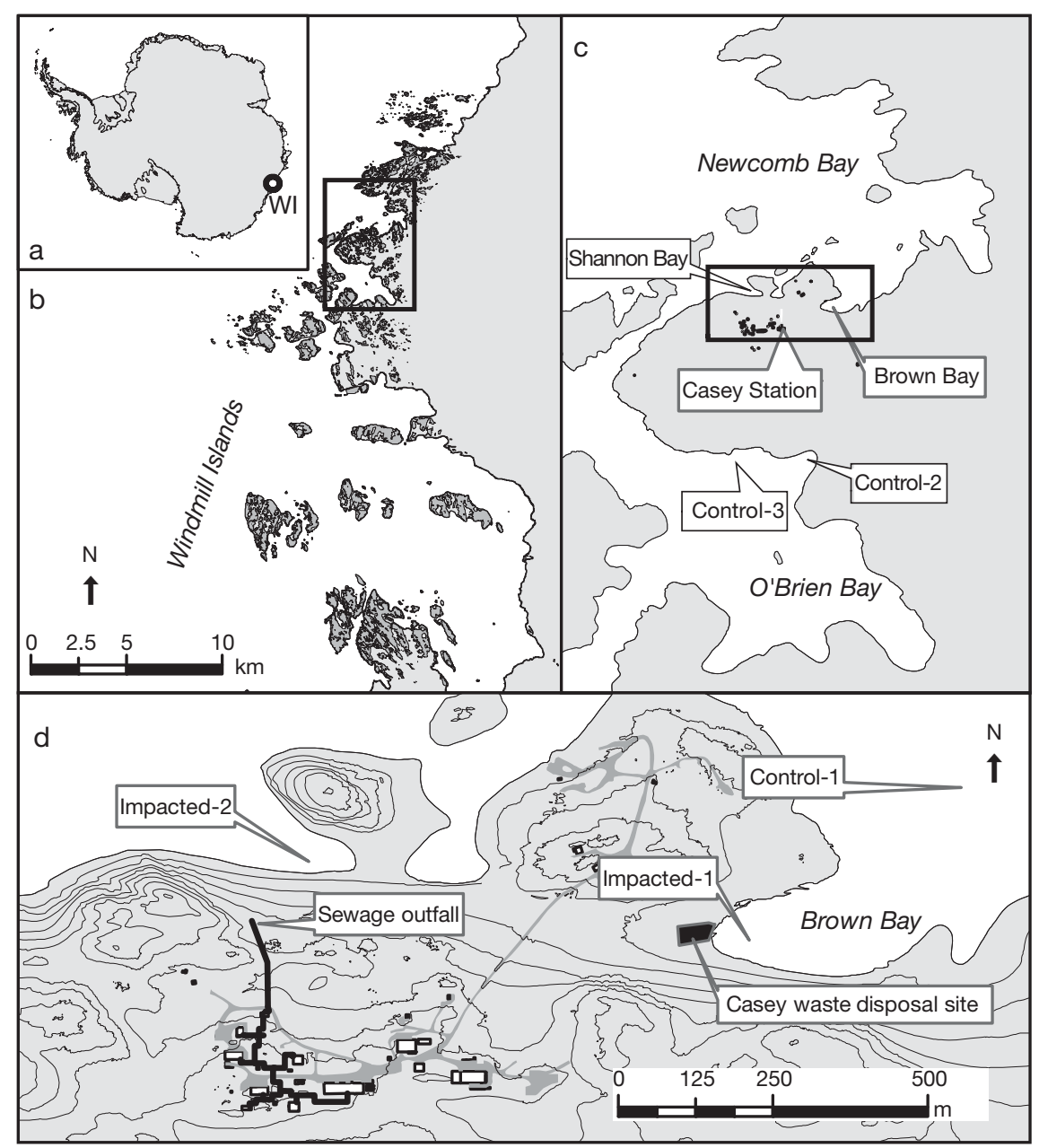

Fig. 1. (a) Windmill Islands (WI) region in Antarctica; (b) Casey station area (boxed) in the Windmill Islands; (c) Casey Station and the tile deployment locations; (d) Casey Station and the deployment locations (Impacted-1, Impacted-2, Control-1) near the sewage outfall and waste disposal site

in these bays is 1.2 to $2 \mathrm{~m}$ thick, and breakout at the sites in this study occurs between December and February in most years.

The old Casey waste disposal site is in Thala Valley, $450 \mathrm{~m}$ northeast of Casey Station, adjacent to Brown Bay (Fig. 1d). Waste material was dumped at the seaward end of Thala Valley and directly into the bay between 1969 and 1986 (Deprez et al. 1999, Snape et al. 2001). During summer, melt water from the surrounding slopes runs through the valley and percolates through the site, entraining contaminants before entering the marine environment and depositing them in Brown Bay (Snape et al. 2001). Sediments in Brown Bay are contaminated by metals and hydrocarbons (Stark et al. 2003b).

The Casey sewage outfall discharges secondary treated and occasionally primary treated sewage ca. $40 \mathrm{~m}$ from the edge of Shannon Bay into the ice cliff. Heated sewage has melted a hole in the ice down to the rock $\sim 5 \mathrm{~m}$ beneath, where it follows an unknown path for 10 s of $m$ into Shannon Bay. A pilot study indicated that there was a distributed discharge along the shore of Shannon Bay rather than a point source, with significant levels of ammonia, phosphorous and bacteria in the water column (Morris et al. 2000).

Materials. The settlement panels consisted of unglazed porcelain tiles $(15 \times 15 \mathrm{~cm})$, with a slightly textured upper surface and $3 \times 3 \mathrm{~cm}$ slightly raised grid ( 1 mm high) on the lower surface. Two tiles were attached $10 \mathrm{~cm}$ apart with silicon to the top edge of a trough made from one-half of a $40 \mathrm{~cm}$ long, $15 \mathrm{~cm}$ diameter stormwater pipe (Fig. 2a). The ends of each trough were open, leaving a semi-cylindrical cavity under each tile. Thus, the upper and lower surfaces were both exposed to predation and currents. The pipe was attached to the top of a mesh bag containing rocks as ballast and the tube was positioned horizontally on the seabed. After collection, the tiles 


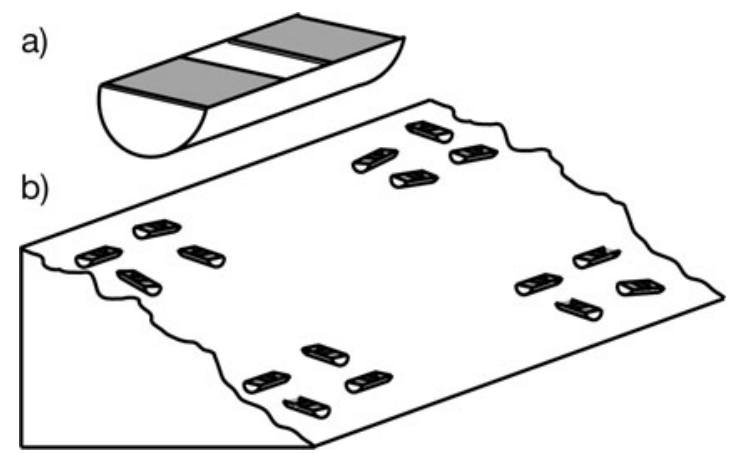

Fig. 2. (a) Two tiles were situated in the top of a trough formed from one-half of a PVC pipe; (b) Experimental design at each site showing groups of 8 tiles, 2 shallow sites and 2 deep sites. At Impacted-1 and Control-1 there was no depth comparison (the seabed was flat) but the layout was the same to test for spatial differences

were photographed using a high-resolution (5 megapixel) digital camera while the organisms were still alive and then preserved in alcohol for a future study of species-level patterns. A grid of 100 evenly spaced points, excluding the outer $1 \mathrm{~cm}$ of each tile, was overlain on the photographs of the upper and lower surfaces of each tile and the biota directly under each point was identified using the categories of taxon shown in Table 1.

Experimental design. Tiles were deployed and collected by divers at 5 locations. Two locations were adjacent to sources of contamination and are known to have contaminated sediments and disturbed soft-sediment communities (Stark et al. 2003a, Stark et al. 2003b): Impacted-1 was in Brown Bay, $\sim 50 \mathrm{~m}$ from the waste disposal site; Impacted-2 was in Shannon Bay, $\sim 100 \mathrm{~m}$ from the sewage outfall (Fig. 1c,d). There were 3 uncontaminated control locations: Control-1 was in the outer part of Brown Bay, $500 \mathrm{~m}$ from the waste disposal site; Control-2 and Control-3 were in O'Brien Bay, south of Casey Station (Fig. 1c). Tiles were deployed at 2 depths at each location ( 7 to $10 \mathrm{~m}$ and 19 to $22 \mathrm{~m}$ ) except at Impacted-1 and Control-1. At each depth, tiles were deployed at 2 sites $\sim 20 \mathrm{~m}$ apart in groups of 8 tiles (4 troughs $\sim 1$ to $2 \mathrm{~m}$ apart), for a total of 32 tiles at each location (Fig. 2b). It was not possible to deploy deep tiles at Impacted-1, as there is no deep habitat near the waste disposal site, nor was it possible to deploy shallow tiles at
Control-1. However, at these 2 locations, 2 groups of 8 tiles (in plots of 4 troughs) were placed $\sim 50 \mathrm{~m}$ apart to examine small-scale spatial variation. Tiles were deployed between 15 November and 31 December 1997. Tiles were collected after 1 yr (between 1 and 23 February 1999) and 3 yr (between 13 and 19 December 2001). One tile was collected from each of 2 randomly selected pipes at each site/depth at each sampling time (a total of 8 per location). Some tiles could not be retrieved, including 2 tiles at Impact-1 during the first collection, and all tiles at Control-2 and 2 tiles at Control-3 during the second collection.

Statistical analyses. Tests of multivariate null hypotheses of no differences among a priori defined groups were done using analysis of similarities (ANOSIM, Clarke 1993) in PRIMER-6 (Plymouth Marine Laboratory). Similarity matrices were based on the Bray-Curtis similarity measure on arcsin of square-root $\left(\sin ^{-1} \sqrt{ }\right.$ prop) transformed proportional cover. This has the effect of decreasing the weighting of very abundant taxa and increasing the weighting of very rare taxa, with little effect on mid-range proportions (Quinn \& Keough 2002). Many studies have used fourth root transformed percentage cover of taxa (e.g. Glasby 2001, Glasby \& Connell 2001); how-

Table 1. Taxonomic categories used in analysis of tiles

\begin{tabular}{|ll|}
\hline & Description \\
\hline Upper surfaces & \\
Diatoms & Biofilm consisting mainly of diatoms \\
Macroalgae & $\begin{array}{l}\text { Red macroalgae only, not possible to identify from } \\
\text { basal growths }\end{array}$ \\
Spirorbids & All dextral coiling (clockwise spiral) \\
Sponge & Very little sponge recorded on upper surfaces, \\
& mainly Homaxinella sp. \\
Encrusting bryozoan & Flat, prostrate cheilostomate colonies \\
Lower surfaces & Red macroalgae only \\
Macroalgae & All dextral coiling (clockwise spiral) \\
Spirorbids & Flat, prostrate cheilostomate colonies \\
Encrusting bryozoans & Upright, branching cyclostomate bryozoan, \\
Branching bryozoans & mainly Hornera sp. \\
Round bryozoans & Uniformly round, domelike colonies \\
Lumpy bryozoans & Encrusting but not prostrate, lumpy in appearance, \\
& mainly Beania sp. \\
Sponge 1 & White/beige small tube-forming sponge \\
Sponge 2 & Beige spiky sponge \\
Sponge 3 & White encrusting sponge \\
Sponge 4 & Orange encrusting sponge \\
Eggs & Possibly gastropod eggs \\
Hydroids & Feather-like thecate hydroids \\
Terrebellids & Tube-building terrebellid polychaetes \\
Ascidian 1 & Clear, colourless ascidian \\
Ascidian 2 & Pale green ascidian \\
Unidentifiable & All other organisms unidentifiable from photos \\
\hline
\end{tabular}


ever, this is an extreme transformation for percentage cover data, which essentially reduces abundances into 4 categories. Relationships between samples were represented graphically using non-metric multidimensional scaling (nMDS) ordinations. Taxa contributing to differences between groups were determined using similarity of percentages analysis (SIMPER, Clarke 1993). A test for small-scale spatial variation was done at 2 locations, Impacted-1 and Control-1, where no depth comparisons were possible but the additional sites provided the replication necessary for an ANOSIM test for differences between sites. Where multiple comparisons were made, the significance level used was adjusted using the sequential Bonferroni correction (Rice 1989). Differences in the variability of assemblages were tested using the program PERMDISP2 (Anderson 2004), which compared the multivariate dispersions among groups on the basis of Bray-Curtis dissimilarity. The test calculates the distances from observations to their group centroids and compares the average of these distances among groups, using ANOVA (Anderson 2006). A p-value is then obtained using permutations of the observations.

Univariate analyses were done using ANOVA on percentage cover of major space occupants. Data were analysed by a 3 factor design, with Time (T), Location (L) and Depth (D) as fixed, orthogonal factors. Cochran's $C$-test was used to test for homogeneity of variances and, where heterogeneous, data were transformed (Underwood 1981). Where heterogeneity of variances could not be removed by transformation and were significant at $\mathrm{p}=0.05$, a probability level of $\mathrm{p}=0.01$ was used. Multiple comparisons among means were done using the StudentNewman-Keuls test (SNK test). To balance the ANOVA for missing tiles, the averages of the other locations (for the missing location Control-2 at $3 \mathrm{yr}$ ) and the mean of the 6 collected tiles at Control-3 were substituted in the analyses and the number of degrees of freedom of the residual was reduced in the ANOVAs (Underwood 1981). Several comparisons were ignored in posthoc tests of means (SNK), as they were not possible to make, including comparisons of depth at Impacted-1 and Control-1 or comparisons involving Control-2 at 3 yr.

\section{RESULTS}

\section{Assemblage composition}

There were major differences in the assemblages recruiting to the upper and lower surfaces of the tiles. Upper surfaces were partially covered by a mixture of semi-consolidated sediment (from 12 to $55 \%$ mean cover), which washed off during processing, and a film of diatoms (from 0 to $59 \%$ mean cover) (Fig. 3a,b). The sediment on tiles was heavily colonised by tanaid crustaceans at some locations, and upper surfaces also had many micro-gastropods. The amount of sedimentary material differed little between locations, times and depths, the only significant difference being at Control-2 after $1 \mathrm{yr}$, where the sediment was almost double that at other locations $\left(\right.$ ANOVA: $\mathrm{T} \times \mathrm{L}, \mathrm{MS}=1417, F_{4,48}=4.7, \mathrm{p}=0.003$; SNK: $\mathrm{p}<0.01$, Fig. 3a). The diatom film was significantly different between locations and times and decreased in the following order after $1 \mathrm{yr}$ : Control-3 = Control $-1>$ Control-2 = Impacted $-2>$ Impacted -1 $\left(\right.$ ANOVA: $\mathrm{T} \times \mathrm{L}, \mathrm{MS}=1907, F_{4,48}=11.6, \mathrm{p}<0.001$; SNK: $p<0.01$, Fig. 3b). By 3 yr, there was very little primary diatom cover on upper surfaces at any location (Fig. 3b).
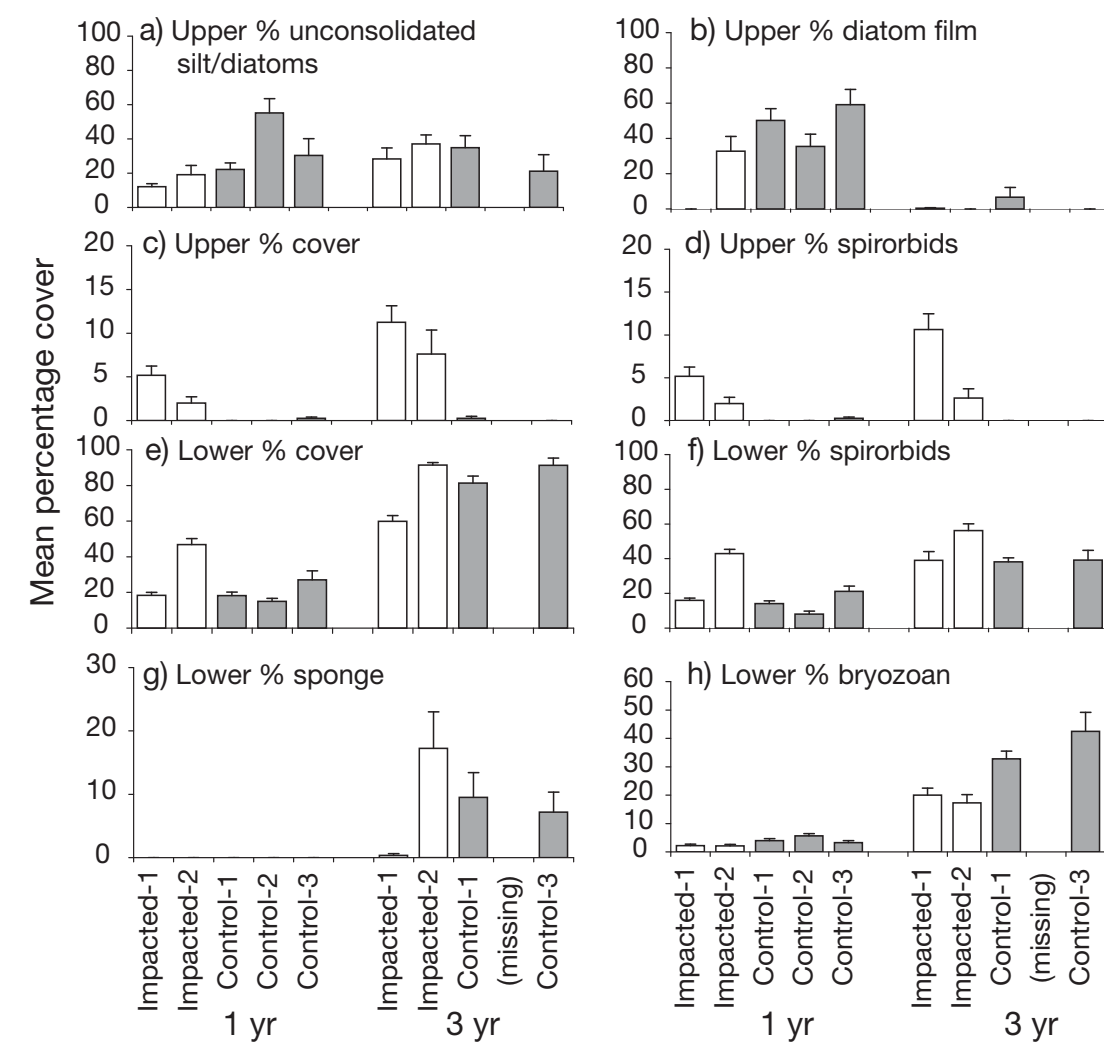

Fig. 3. Mean percentage cover $(+\mathrm{SE})$ of major groups of sessile organisms at each location at 1 and 3 yr. White bars represent impacted locations 
Total cover of sessile organisms on upper surfaces (excluding diatoms) ranged from 0 to $5 \%$ after $1 \mathrm{yr}$ and 0 to $11 \%$ after 3 yr (Fig. 3c) and consisted mainly of spirorbid polychaetes (Fig 3d). There were significant differences between locations, with Impacted-1 having significantly greater cover than Impacted-2, which was greater than all other locations at both times (SNK: $\mathrm{p}<$ 0.01, Table 2a, Fig. 3c). Total cover on the upper surfaces also increased significantly at the 2 impacted locations from $1 \mathrm{yr}$ to $3 \mathrm{yr}$ (SNK: p < 0.01, Table 2a, Fig. 3c), but composition differed, with Impacted-1 consisting mainly of spirorbid polychaetes $(1 \mathrm{yr}=$ $5.2 \%, 3 \mathrm{yr}=10.6 \%$ ) and Impacted-2 shifting from spirorbids to macroalgae $(1 \mathrm{yr}=2 \%$ spirorbids; $3 \mathrm{yr}=$ $2.6 \%$ spirorbids, $5 \%$ macroalgae). Little was found growing on the upper surfaces at other locations (Fig. 3c).

Biotic assemblages on the lower surfaces occupied between 15 and $47 \%$ mean total cover after $1 \mathrm{yr}$ and between 60 and $91 \%$ after $3 \mathrm{yr}$ and consisted almost entirely of spirorbids, bryozoans and sponges (Fig. 4). Bare space was predominant at $1 \mathrm{yr}$ and spirorbids were the dominant colonist, but by 3 yr bryozoans and sponges were significant components of the assemblage and there was little remaining unoccupied space, except at Impacted-1 (Fig. 4). Total percentage cover on the lower surfaces was significantly greater at $3 \mathrm{yr}$ at all locations (SNK: $\mathrm{p}<0.01$, Table 2b, Fig. 3e). There were significant $\mathrm{T} \times \mathrm{L}$ interactions in lower total $\%$ cover: at 1 yr Impacted- $2>$ Control-3 $>$ all others (SNK: $\mathrm{p}<0.05$ Table 2b, Fig. 3e); at 3 yr there were fewer differences in total cover, with Control-3 and Impacted- $2>$ all others, and Impacted- $1<$ all others (SNK: $p<0.05$, Table $2 b$, Fig. 3e). The only effect of depth on total lower cover was at O'Brien-3, which had greater \% cover at deep sites at $1 \mathrm{yr}$ and greater \% cover at shallow sites at $3 \mathrm{yr}(\mathrm{T} \times \mathrm{L} \times \mathrm{D}$ interaction, SNK: $\mathrm{p}<0.05$, Table $2 b$ ).

Percentage cover of spirorbids on the upper surfaces was greatest at the 2 impacted locations, with very little recruitment at the other locations (Table 2c, Fig. $3 d$ ). On the lower surfaces, spirorbid cover ranged from a mean of 8 to $43 \%$ after 1 yr, and after 3 yr was very similar at Impacted-1, Control-1 and Control-3

Table 2. Results of 3-factor ANOVA testing for differences in cover of major taxa between times, locations and depths. df: degrees of freedom; MS: mean square estimates; $C$ : Cochran's $C$-test result; untrans: data not transformed; sqrt: square root; NS: not significant. Significant results in bold. $F$ versus Residual in all cases

\begin{tabular}{|c|c|c|c|c|c|c|c|}
\hline Source & $\mathrm{df}$ & MS & $F$ & $\mathrm{p}$ & MS & $F$ & $\mathrm{p}$ \\
\hline $\begin{array}{l}\text { (a) Upper \% cover }\left(\ln _{x+1}\right) \text {, } \\
(C=0.33, p<0.01)\end{array}$ & & & & & \multicolumn{3}{|c|}{$\begin{array}{l}\text { (b) Lower \% cover (untrans), } \\
(C=0.18, \mathrm{NS})\end{array}$} \\
\hline Time & 1 & 8.61 & 46.04 & $<0.0001$ & 62435.66 & 1534.27 & $<0.0001$ \\
\hline Location & 4 & 11.94 & 63.84 & $<0.0001$ & 2108.44 & 51.81 & $<0.0001$ \\
\hline Depth & 1 & 0.06 & 0.34 & 0.56 & 152.17 & 3.74 & 0.059 \\
\hline Time $\times$ Location & 4 & 2.23 & 11.93 & 0.0001 & 559.15 & 13.74 & $<0.0001$ \\
\hline Time $\times$ Depth & 1 & 0.05 & 0.28 & 0.6 & 143.11 & 3.52 & 0.067 \\
\hline Location $\times$ Depth & 4 & 0.14 & 0.76 & 0.56 & 112.96 & 2.78 & 0.037 \\
\hline Time $\times$ Location $\times$ Depth & 4 & 0.05 & 0.29 & 0.88 & 329.95 & 8.11 & $<0.0001$ \\
\hline Residual & 48 & 0.19 & & & 40.69 & & \\
\hline $\begin{array}{l}\text { (c) Upper spirorbids }\left(\ln _{x+1}\right) \text {, } \\
(C=0.34, \mathrm{p}<0.01)\end{array}$ & & & & & \multicolumn{3}{|c|}{$\begin{array}{l}\left.\text { (d) Lower \% spirorbids } \text { (sqrt }_{x+1}\right) \text {, } \\
(C=0.23, p<0.05)\end{array}$} \\
\hline Time & 1 & 3.05 & 26.27 & $<0.0001$ & 94.10 & 265.63 & $<0.0001$ \\
\hline Location & 4 & 11.00 & 94.84 & $<0.0001$ & 13.31 & 37.59 & $<0.0001$ \\
\hline Depth & 1 & 0.42 & 3.58 & 0.065 & 0.93 & 2.63 & 0.11 \\
\hline Time $\times$ Location & 4 & 1.76 & 15.20 & $<0.0001$ & 4.44 & 12.53 & $<0.0001$ \\
\hline Time $\times$ Depth & 1 & 0.45 & 3.87 & 0.055 & 2.57 & 7.25 & 0.01 \\
\hline Location $\times$ Depth & 4 & 0.19 & 1.66 & 0.18 & 0.79 & 2.22 & 0.08 \\
\hline Time $\times$ Location $\times$ Depth & 4 & 0.55 & 4.74 & 0.003 & 2.22 & 6.26 & 0.0004 \\
\hline Residual & 48 & 0.12 & & & 0.35 & & \\
\hline $\begin{array}{l}\text { (e) Lower \% sponge }\left(\text { sqrt }_{x+1}\right) \text {, } \\
(C=0.36, p<0.01)\end{array}$ & & & & & \multicolumn{3}{|c|}{$\begin{array}{l}\text { (f) Lower \% bryozoan }\left(\text { sqrt }_{x+1}\right) \text {, } \\
(C=0.21, \text { NS) }\end{array}$} \\
\hline Time & 1 & 58.93 & 247.39 & $<0.0001$ & 209.00 & 615.01 & $<0.0001$ \\
\hline Location & 4 & 3.96 & 16.64 & $<0.0001$ & 5.45 & 16.05 & $<0.0001$ \\
\hline Depth & 1 & 10.93 & 45.88 & $<0.0001$ & 0.10 & 0.28 & 0.6 \\
\hline Time $\times$ Location & 4 & 3.96 & 16.64 & $<0.0001$ & 2.68 & 7.90 & $<0.0001$ \\
\hline Time $\times$ Depth & 1 & 10.93 & 45.88 & $<0.0001$ & 1.16 & 3.43 & 0.07 \\
\hline Location $\times$ Depth & 4 & 2.49 & 10.44 & $<0.0001$ & 0.99 & 2.93 & 0.03 \\
\hline Time $\times$ Location $\times$ Depth & 4 & 2.49 & 10.44 & $<0.0001$ & 0.77 & 2.27 & 0.075 \\
\hline Residual & 48 & 0.24 & & & 0.34 & & \\
\hline
\end{tabular}




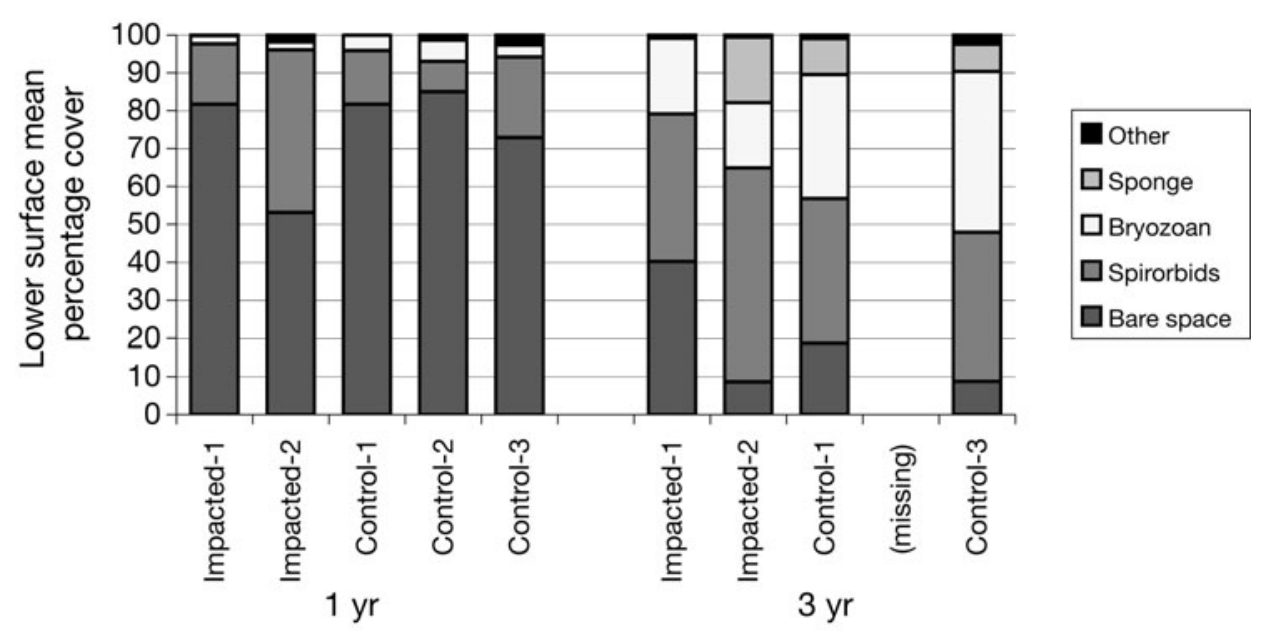

Fig. 4. Relative proportion of major taxa on lower surfaces of tiles at each location at 1 and 3 yr

(mean $\sim 39 \%$ ), with a mean of $56 \%$ cover at Impacted2 (Fig. 3f). Spirorbid cover was significantly greater at Impacted-2, the sewage outfall (Fig. 3f), than all other locations at both times $(\mathrm{T} \times \mathrm{L}, \mathrm{SNK}: \mathrm{p}<0.05$, Table $2 \mathrm{~d})$. There was no consistent pattern of spirorbid recruitment in relation to depth.

Almost no sponge cover was recorded after $1 \mathrm{yr}$, but by 3 yr there had been significant recruitment on lower surfaces (Fig. 3g). Recruitment was lowest after 3 yr at Impacted-1 (mean $0.37 \%$ ) and highest at Impacted-2 (mean $17.25 \%)(\mathrm{T} \times \mathrm{L}$, SNK: Impacted-2 $>$ Control-1 = Control-3 $>$ Impacted-1, p $<0.01$, Table 2e). At the 2 sites where a depth comparison was possible (Impacted-2 and Control-3) there was significantly greater sponge cover on tiles at the deep sites $(\mathrm{T} \times \mathrm{L} \times \mathrm{D}$, SNK: deep $>$ shallow at both locations, $\mathrm{p}<0.01$, Table $2 \mathrm{e}$ ).

Bryozoan cover on the lower surfaces ranged from 2 to $6 \%$ at $1 \mathrm{yr}$ and 17 to $43 \%$ at $3 \mathrm{yr}$, and was least at both impacted locations at 1 and 3 yr (Fig. 3h). At 1 yr the only significant difference was that Control-2 had greater bryozoan cover than Impacted-1 $(\mathrm{T} \times \mathrm{L}, \mathrm{SNK}$ : $\mathrm{p}<0.05$, Table 2f). After $3 \mathrm{yr}$ there were significant differences among locations with Control-3 > Control$1>$ Impacted-1 = Impacted-2 $(\mathrm{T} \times \mathrm{L}$, SNK: $\mathrm{p}<0.01$, Table 2f). There were no significant differences between depths.

\section{Assemblage patterns}

Most hypotheses were supported, with clear assemblage patterns related to spatial effects, human impacts, period of deployment and depth, which can be seen in nMDS ordinations of the combined upper and lower surfaces (Figs. 5 to 7). There were no significant differences in assemblage variability at this higher-taxon level.

\section{Spatial patterns}

Control locations were not significantly different at 1 yr, but they were by 3 yr (Table 3), although Control-2 was not sampled at this time. The overlap of control samples in the nMDS apparent at $1 \mathrm{yr}$ is clearly not evident at $3 \mathrm{yr}$, when distinct separation is seen (Fig. 5). Differences between Control-1 and Control-3 were mainly due to the different bryozoan categories, with particular forms more abundant at one location. SIMPER analysis indicated that there were large differences in cover of branching bryozoans and lumpy bryozoans, both of which are thought to represent single species. At the 2 locations where within-location, small-scale spatial variation

\begin{tabular}{|lll}
\hline A $1 \mathrm{yr}$ - Impacted-1 & $\square$ 1 yr - Control-2 & O 3 yr - Impacted-2 \\
1 yr - Impacted-2 & $\diamond 1 \mathrm{yr}$ - Control-3 & $\nabla$ 3 yr - Control-1 \\
$\nabla 1 \mathrm{yr}$ - Control-1 & $\boldsymbol{\Delta}$ 3 yr - Impacted-1 & $\diamond 3 \mathrm{yr}$ - Control-3
\end{tabular}

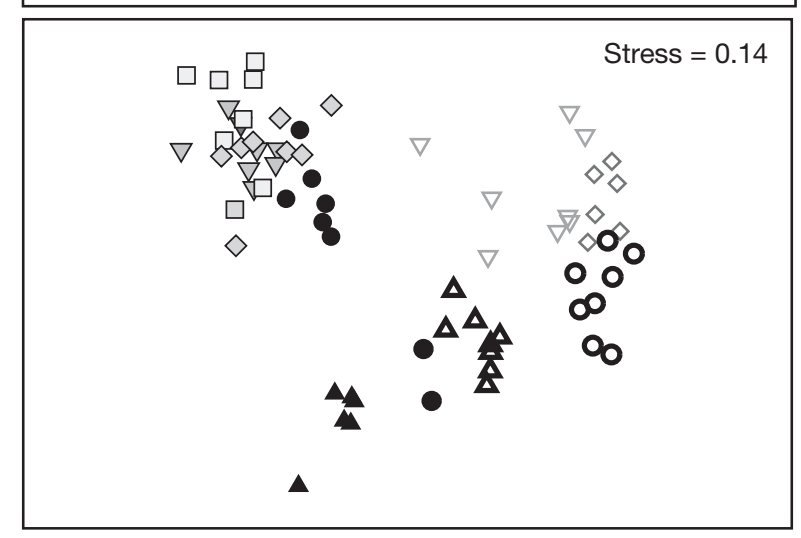

Fig. 5. Non-metric multidimensional scaling (nMDS) ordination of assemblages (combined upper and lower surfaces) on each tile at each location at 1 and $3 \mathrm{yr}$ 


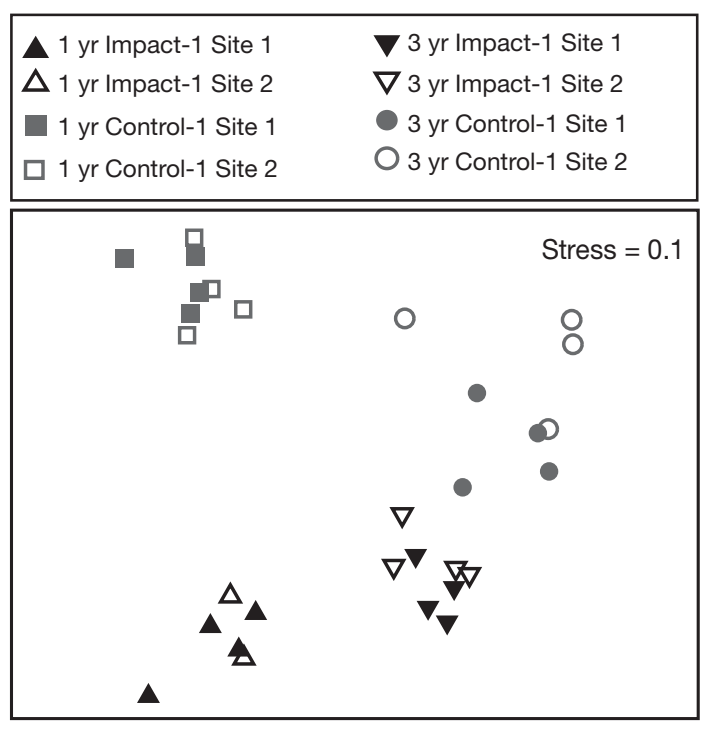

Fig. 6. nMDS scaling ordination of assemblages (combined upper and lower surfaces) on tiles at different sites ( 50 m apart) at Impacted-1 and Control-1 at 1 and 3 yr

was tested (Impacted-1 and Control-1), there were no significant differences in assemblages between the 2 sites ( $~ 50 \mathrm{~m}$ apart) after $1 \mathrm{yr}$, but after $3 \mathrm{yr}$ there was a small difference at Control-1 (Table 4, Fig. 6).

Human impacts

Impacted-1 (the waste disposal site) was the location that differed the most from other locations at both 1 and 3 yr (Table 3); it also differed significantly from the controls as a group ( 1 yr: $\mathrm{R}=0.99, \mathrm{p}=0.001$; $3 \mathrm{yr}: \mathrm{R}=0.69, \mathrm{p}=0.001$ ). It was also one of the least variable locations (Table 5). Impacted-2 (the sewage outfall) was the most similar to Impacted-1 after $1 \mathrm{yr}$ and was significantly different from all controls (Table 3, Fig. 5), and the controls as a group $(1$ yr: $\mathrm{R}=0.51, \mathrm{p}=$ $0.001)$, although this also decreased by 3 yr $(\mathrm{R}=0.41, \mathrm{p}=0.001)$. Impacted -2 was also the most variable location (Table 5). Impacted-1 and Impacted-2 are distinct from all other locations in the nMDS ordination for 1 and 3 yr (Fig. 5). There is some overlap of samples from Impacted-2 with those from control locations, but no overlap of Impacted-1 with controls. The impacted locations also changed the least from 1 to 3 yr (Fig. 5) and had the lowest ANOSIM R-values in the 1 and 3 yr comparisons (Impacted-1:
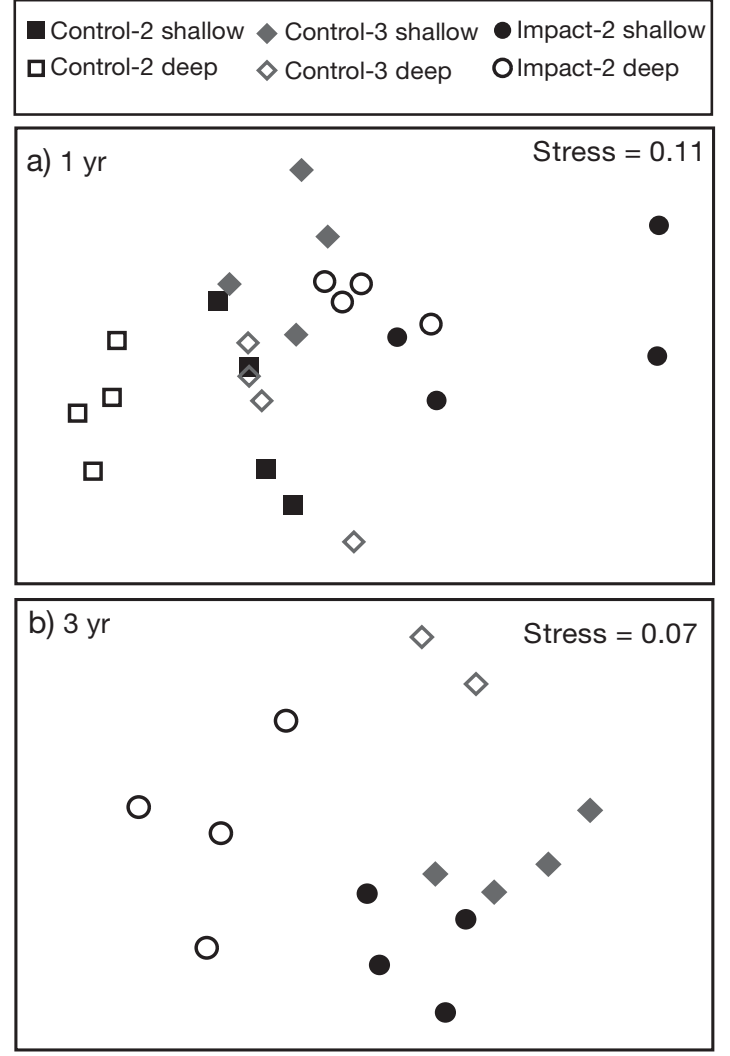

Fig. 7. nMDS ordination of assemblages (combined upper and lower surfaces) on tiles at shallow and deep sites at (a) $1 \mathrm{yr}$ and (b) 3 yr

$\mathrm{R}=0.94, \mathrm{p}=0.001 ;$ Impacted $-2: \mathrm{R}=0.91, \mathrm{p}=0.001)$. Control-3 showed the greatest change from 1 to $3 \mathrm{yr}$ (Fig. 5, $\mathrm{R}=1.0, \mathrm{p}=0.001$ ).

Although there was very little recruitment and very few taxa on the upper surfaces of the tiles, SIMPER analysis indicated that the upper surfaces were important in contributing to differences between impacted

Table 3. Results of analysis of similarities (ANOSIM) tests comparing locations at 1 and $3 \mathrm{yr}$, showing R-value (with p-value). Significant results in bold; significance level adjusted using sequential Bonferroni procedure

\begin{tabular}{|c|c|c|c|c|}
\hline & Impacted-1 & Impacted-2 & Control-1 & Control-2 \\
\hline \multicolumn{5}{|l|}{$1 \mathrm{yr}$} \\
\hline Impacted-2 & $0.83(0.001)$ & & & \\
\hline Control-1 & $1(0.002)$ & $0.54(0.001)$ & & \\
\hline Control-2 & $1(0.002)$ & $0.63(0.001)$ & $0.06(0.22)$ & \\
\hline Control-3 & $0.99(0.003)$ & $0.37(0.001)$ & $0.15(0.03)$ & $0.21(0.013)$ \\
\hline \multicolumn{5}{|l|}{$3 \mathrm{yr}$} \\
\hline Impacted-2 & $0.89(0.001)$ & & & \\
\hline Control-1 & $0.71(0.001)$ & $0.62(0.001)$ & & \\
\hline Control-3 & $0.98(0.001)$ & $0.43(0.006)$ & $0.47(0.003)$ & \\
\hline
\end{tabular}


Table 4. ANOSIM results for comparison of sites within locations. Significant results in bold, corrected for multiple comparisons

\begin{tabular}{|lcc|}
\hline Site 1 vs. Site 2 & $\mathrm{R}$ & $\mathrm{p}$ \\
\hline 1 yr Impacted-1 & -0.11 & 0.53 \\
1 yr Control-1 & -0.16 & 0.86 \\
3 yr Impacted-1 & -0.08 & 0.63 \\
3 yr Control-1 & $\mathbf{0 . 4 3}$ & $\mathbf{0 . 0 3}$ \\
\hline
\end{tabular}

Table 5. PERMDISP2 multivariate analysis of mean distance from centroid and standard error for each location and time, in ascending order

\begin{tabular}{|lcc|}
\hline & Average & SE \\
\hline $\mathbf{1}$ yr & & \\
Control-1 (waste site) & 12.23 & 1.49 \\
Impacted-1 & 12.62 & 2.14 \\
Control-3 & 13.49 & 3.22 \\
Control-2 & 17.15 & 1.04 \\
Impacted-2 (sewage) & 18.18 & 3.13 \\
$\mathbf{3}$ yr & & \\
Impacted-1 (waste site) & 15.82 & 1.99 \\
Control-1 & 18.81 & 2.17 \\
Control-3 & 17.81 & 1.62 \\
Impacted-2 (sewage) & 19.40 & 1.97 \\
\hline
\end{tabular}

and control locations. At $1 \mathrm{yr}$ at Impacted-1 and Impacted-2, spirorbids on both surfaces and diatoms on the upper surface cumulatively accounted for 82 and $75 \%$, respectively, to the total dissimilarity with the controls. After $3 \mathrm{yr}$, spirorbids were the only taxa on the upper surfaces that were still an important contributor to differences between control and impacted locations, although this contribution was much reduced. Taxa such as sponges and bryozoans on the lower surfaces were much more important in discriminating between controls and impacted locations at $3 \mathrm{yr}$.

\section{Depth}

At the locations where a depth comparison was possible (Impacted-2, Control-2 and Control-3), there were significant differences between assemblages recruiting to tiles at shallow and deep sites (Table 6, Fig. 7a) for all 3 locations at 1 yr and for Impacted-2 and Control-3 at 3 yr (Fig. 7b). SIMPER analysis indicated that sponge cover was greater at deep sites than shallow, and that spirorbids tended to have greater cover at shallow sites. Bryozoans were initially more abundant at deep sites at 1 yr (except for Control-3), but at 3 yr they were more abundant at shallow sites.
Table 6. ANOSIM results for tests of differences between depths at each location and time. All p-values represent best possible result for the number of permutations possible

\begin{tabular}{|lcc|}
\hline & $\mathrm{R}$ & $\mathrm{p}$ \\
\hline $\mathbf{1}$ yr & & \\
Control-2 shallow vs. deep & 0.90 & 0.03 \\
Control-3 shallow vs. deep & 0.35 & 0.03 \\
Impacted-2 shallow vs. deep & 0.35 & 0.05 \\
$\mathbf{3}$ yr & & \\
Control-3 shallow vs. deep & 0.93 & 0.07 \\
Impacted-2 shallow vs. deep & 0.81 & 0.03 \\
\hline
\end{tabular}

\section{DISCUSSION}

This study demonstrated that there are patterns in the recruitment and development of sessile epibiotic assemblages in Antarctica at higher taxonomic levels. A mix of classification levels was used, including functional taxonomic units (such as encrusting bryozoans), but even when the data was aggregated at the phylum level the patterns were very similar.

There was no pattern of spatial differences between controls after 1 yr, but by 3 yr assemblages recruiting to tiles showed clear differences between control locations, separated by several $\mathrm{km}$. This comparison must be interpreted with some caution due to the absence of data from the third control location. Differences between controls at 3 yr were largely due to differences in the cover of various bryozoan groups, which probably reflect processes operating at small spatial scales, such as local differences in availability of recruits, or small-scale environmental differences, such as currents. Spatial variability in developing epibiotic assemblages is well-documented in non-polar regions, from scales of 10s of $\mathrm{m}$ to $\mathrm{km}$ (Keough 1983, Butler 1986, Glasby 1998). At Ryder Bay on the Antarctic Peninsula, colonisation and assemblage development at species level was highly site-specific and depth-dependant, but higher taxa patterns were not examined (Bowden et al. 2006). The level of variability within locations at Casey generally increased from 1 to 3 yr as the communities became larger (occupied more space) and more complex (more taxa). At the 2 sites where spatial variation at small scales was examined there were no differences between sites $\sim 50 \mathrm{~m}$ apart at $1 \mathrm{yr}$, due to variation within sites at scales of 1 to $10 \mathrm{~m}$, but by $3 \mathrm{yr}$ there were small but significant differences within the control locations. The nMDS ordination of all locations, (Fig. 5) also illustrates the amount of variation that occurred between replicate samples within a location, and there was considerable spread of samples for some locations. This demonstrates the need for adequate spatial replication when comparing locations, with 
replicates placed from 10 to $50 \mathrm{~m}$ apart to incorporate small-scale variability. Similar results were found by Glasby (1998) in a study of spatial variation in a temperate estuary, and other studies have also stressed the importance of capturing small-scale variation in larger-scale comparisons (Morrisey et al. 1992, Underwood 1993). While it is clear that there was small-scale variation within some locations in the present study, some of which may be attributed to depth effects, the most obvious pattern was the difference between control and impacted assemblages.

\section{Human impacts}

The impacted locations were significantly different from the control locations after $1 \mathrm{yr}$ and while all locations were significantly different from each other after $3 \mathrm{yr}$, the impacted locations were still distinctly different from the control locations. The 2 differing types of impact also appear to have had different effects. These differences in assemblages may represent a response to anthropogenic disturbance that can be characterised at higher-taxon levels. Patterns of response to contamination at high taxonomic levels have been found in Antarctic soft-sediment assemblages (Lenihan et al. 2003), but hard substrata assemblages in Antarctica have not previously been examined in this way.

After $1 \mathrm{yr}$ the upper surfaces of tiles adjacent to the waste disposal site at Brown Bay (Impacted-1) were very different from those at the control locations, with greater total cover, which consisted mainly of spirorbids, but with little to no diatom film, and these differences persisted after 3 yr. In contrast, the lower surfaces of tiles adjacent to the waste disposal site had the least cover of biota, almost no sponges and significantly less bryozoan cover than the controls, but the cover of spirorbids did not differ from the control locations. These assemblages also exhibited the least amount of change between 1 and 3 yr. The contaminants in Brown Bay are mainly metals from the waste disposal site, which leach into the bay during summer melt and are highly concentrated in sediments of the bay (Stark et al. 2003b). Bryozoans, in particular their larval stage, are sensitive to metals (Wisely \& Blick 1967, Henry et al. 1989), with reduced survivorship of recruits after exposure to dissolved metals $(\mathrm{Ng} \&$ Keough 2003). Temperate sponges are also sensitive to metals, which can affect their growth, fecundity and survival (Cebrian et al. 2003). Sponges filter large volumes of water and accumulate and exhibit toxic responses to metals (Patel et al. 1985, Hansen et al. 1995). In a survey of temperate bays contaminated by industrial pollution, very few species of sponges were found (Pansini \& Pronzato 1975). This study provides preliminary evidence that metals in Brown Bay, either dissolved or in resuspended sediments, are affecting the recruitment and development of sponges and bryozoans.

Assemblages in Shannon Bay, the location of the sewage outfall, were more similar to the control locations than the waste disposal site, but there were some significant differences. The lower surfaces of tiles at Shannon Bay had the greatest total cover of biota, the greatest cover of spirorbid polychaetes ( 2 to 5 times that recorded at control locations) and sponges (at least twice that recorded at controls by $3 \mathrm{yr}$ ), but the least cover of bryozoans. In temperate ecosystems sponges have been found to be generally tolerant of sewage pollution; for example, Terlizzi et al. (2002) found that a sewage outfall did not affect the distribution of sponges, but affected the pattern of variability in the structure of sponge assemblages around the outfall site. Similarly, in this study, Shannon Bay had the greatest variability in assemblage structure and composition. In temperate marine bays heavily polluted by sewage, Pansini \& Pronzato (1975) found rich assemblages of sponges and Muricy (1991) found that sewage did not affect the total percentage cover of sponges on vertical subtidal surfaces, though it did reduce the diversity and evenness of sponge assemblages. This study did not identify sponges to species, so it is not possible to determine whether sponge assemblages were less diverse at Shannon Bay, but the evidence suggests that the cover of sponges on tiles is greater in the presence of sewage. Sewage may be being directly utilised as a food source or it may indirectly affects sponges by influencing local primary production and increasing available food. This may also explain the increased cover of spirorbid polychaetes at the outfall site. Conversely, bryozoan cover was much lower than controls in a similar manner to the waste disposal site, suggesting that bryozoans are possibly intolerant of sewage or eutrophication in Antarctica. Alternatively, bryozoan recruitment at Shannon Bay may be inhibited by biological interactions, such as allelopathy (Davis et al. 1991, Dobretsov et al. 2004), although the low sponge and low bryozoan cover at Brown Bay does not support this hypothesis.

This study provides preliminary evidence that Antarctic bryozoans and sponges are sensitive to anthropogenic disturbance. Sponges appear tolerant of sewage and may even respond positively to eutrophication, while bryozoans appear sensitive to it. Sponges and bryozoans appear to be intolerant of contaminants from the waste disposal site, most of which are metals, but some of which are hydrocarbons (Stark et al. 2003b, 2005). Marine invertebrates exposed to stress (such as pollution) during their larval stage have 
been shown to exhibit impaired performance in later life stages (Maldonado \& Young 1999, Ng \& Keough 2003). It is possible that larval/settlement-stage recruits are being affected by pollution at Casey, resulting in differences in recruitment and assemblage development. However, there remains a distinct requirement for ecotoxicological testing of these Antarctic taxa (Chapman \& Riddle 2003). Some marine invertebrates, particularly annelids, are tolerant of some pollutants and even posses detoxification mechanisms, (e.g. Marcano et al. 1996), which, combined with opportunistic life history strategies (e.g. high fecundity, short generation time, year-round breeding, widespread dispersal), see them successfully inhabit contaminated areas. Spirorbids appear to be responding in an opportunistic manner to both disturbance types at Casey, as they were more abundant at disturbed locations on both upper and lower surfaces. On upper surfaces they were the main colonists, particularly at disturbed locations. There are tiles still in place at all locations at Casey, and it will be interesting to see whether these differences in assemblages are maintained in the long term.

The deployment of settlement panels in monitoring experiments appears to be a potentially useful method in Antarctica. Patterns of differences between control and impacted locations were clear, even with coarse taxonomic resolution. Coarse resolution in such monitoring situations allows for fast analysis times after tile collection and does not require expert taxonomic knowledge to identify to species level. However, further examination of species-level patterns would enable a better understanding of the processes influencing these assemblages. Other factors to consider when deploying settlement panels for monitoring in Antarctica include uniform depth, adequate smallscale spatial replication and analysis of both lower and upper surfaces. Ideally for monitoring they should be supplemented with other techniques to provide further information on ecosystem status, such as soft sediments.

\section{Colonisation and succession patterns in Antarctica}

This study demonstrated some clear patterns of epifaunal recruitment and assemblage development in Antarctica. Structurally, there was very little recruitment to upper surfaces and this seems to be a general pattern for Antarctica (Stanwell-Smith \& Barnes 1997, Bowden et al. 2006). This may be a result of either presettlement preferences to lower surfaces, or post-settlement mortality of recruits on upper surfaces. Bowden (2005) found no evidence for settlement preferences in a study of recruitment at monthly inter- vals over 17 mo at Ryder Bay, Antarctic Peninsula, with comparable rates of recruitment on upper and lower surfaces and no species recruiting preferentially to upper or lower surfaces, other than algae. However, there were very different assemblages on upper and lower surfaces after 3 yr (Bowden et al. 2006), with similar patterns to those in the present study. Bowden (2005) suggested that these differences were most likely due to post-settlement mortality; however, plates were replaced monthly, which would limit any buildup of sediment on the upper surfaces. In this study there was significant accumulation of sediment on upper surfaces-between $12 \pm 1.7 \%$ (mean \pm SE) and $55 \pm$ $8.2 \%$ cover. Thus, the presence of sediment may be influencing the settlement of larvae, with less available habitat (upper surfaces) and/or preferential habitat selection of sediment-free surfaces (lower surfaces). Alternatively, sediment deposition may cause post-settlement mortality via smothering. The effect of sedimentation on recruitment, however, has not been tested in Antarctica. In addition, the sediment on the upper surfaces was heavily colonised by tanaid crustaceans of the genus Nototanais, which are voracious predators of juvenile and small invertebrates (Oliver \& Slattery 1985).

The general pattern of assemblage development and succession at Casey is of diatoms and spirorbids as pioneers on upper surfaces, with little development by 3 yr. On lower surfaces spirorbids and bryozoans were the pioneer colonists, and after $3 \mathrm{yr}$, spirorbids were still dominant but bryozoans occupied significantly more space and sponges also comprised a significant component of the assemblage.

This study reports some recruitment patterns that contrast with those found in other areas of Antarctica. Signy Island has very slow rates of colonisation on lower surfaces at 5 and $25 \mathrm{~m}$ depth, with $<2$ to $6 \%$ cover after 15 mo deployment and $<9 \%$ after 21 mo (Stanwell-Smith \& Barnes 1997). This may be a consistent pattern for Signy Island, as Barnes (1996) reported similar colonisation rates after $2 \mathrm{yr}$ in an earlier study at the same location. At Ryder Bay the mean cover on lower surfaces after 3 yr ranged from $\sim 25$ to $68 \%$ at 8 $\mathrm{m}$ and $\sim 6$ to $70 \%$ at $20 \mathrm{~m}$ at 3 locations (Bowden et al. 2006). Mean colonisation rates at Casey are greater than other areas previously reported in Antarctica, with mean cover after 3 yr ranging from 81 to $91 \%$ at 3 control locations, with up to $98 \%$ mean cover at 7 to 10 $\mathrm{m}$ and 79 to $81 \%$ cover at 19 to $22 \mathrm{~m}$. Some areas of Antarctica appear to be subject to considerable interannular variation in recruitment, possibly as a result of large-scale oceanographic variations. Settlement panels deployed at McMurdo Station in the 1970s had almost no recruitment after 5 yr, but 10 yr after deployment were described as 'well colonised' by bryozoans, 
soft corals and sponges (Dayton 1989). The assemblage composition and structure at Casey is similar to both the Signy Island and Ryder Bay assemblages, with spirorbids and bryozoans dominant in all 3 regions. However, at Casey after 3 yr, sponges were a notable component of the assemblage (up to $17 \%$ ), unlike the other 2 regions. Further evidence of regional differences comes from King George Island, where after 3 yr the substratum was almost entirely dominated by solitary ascidians (Rauschert 1991).

\section{CONCLUSIONS}

This study represents the first use of settlement panels in a monitoring context in Antarctica, which is a very difficult environment to work in, and where there is a real need for simple, robust techniques suited to a standardised monitoring procedure. It is also the first study of epibiotic colonisation from East Antarctica. Clearly there are significant regional differences in rates of colonisation and in assemblage structure in Antarctica. Some broadly separated regions appear to have similar dominant colonists (spirorbids and bryozoans) and colonisation rates, and thus the applicability of settlement panels for monitoring in other regions may be similar. Some tiles are still deployed at Casey and will be sampled in the future, when species-level analyses will also be done for the entire collection. Further work at the species level will enable the mechanisms and processes behind such patterns to be better understood, and will increase our understanding of anthropogenic impacts on Antarctic ecosystems.

Acknowledgements. The author is grateful to G. Anderson and M. Riddle for assistance with setting up the experiment; P. Goldsworthy, A. Tabor, and M. Riddle for diving assistance; G. Johnstone and A. Lee for laboratory assistance; S. Pearce and members of the 50th and 51st ANARE expeditions to Casey; and G. Clark and G. Johnstone for commenting on the manuscript. This work was supported by the Australian Antarctic Division (AAS project 2201).

\section{LITERATURE CITED}

Anderson MJ (2004) PERMDISP: a FORTRAN computer program for permutational analysis of multivariate dispersions (for any two-factor ANOVA design) using permutation tests. Department of Statistics, University of Auckland

Anderson MJ (2006) Distance-based tests for homogeneity of multivariate dispersions. Biometrics 62:245-253

Anderson MJ, Diebel CE, Blom WM, Landers TJ (2005) Consistency and variation in kelp holdfast assemblages: spatial patterns of biodiversity for the major phyla at different taxonomic resolutions. J Exp Mar Biol Ecol 320:35-56

Barnes DKA (1996) Low levels of colonisation in Antarctica: the role of bryozoans in early community development. In:
Gordon DP, Smith AM, Grant-Mackie JA (eds) Bryozoans in space and time. National Institute of Water and Atmospheric Research, Wellington

> Bowden DA (2005) Seasonality of recruitment in Antarctic sessile marine benthos. Mar Ecol Prog Ser 297:101-118

Bowden DA, Clarke A, Peck LS, Barnes DKA (2006) Antarctic sessile marine benthos: colonisation and growth on artificial substrata over three years. Mar Ecol Prog Ser 316: $1-16$

Butler AJ (1986) Recruitment of sessile invertebrates at five sites in Gulf St. Vincent, South Australia. J Exp Mar Biol Ecol 97:13-36

> Cebrian E, Martí R, Uriz J, Turon X (2003) Sublethal effects of contamination on the Mediterranean sponge Crambe crambe: metal accumulation and biological responses. Mar Pollut Bull 46:1273-1284

Chapman PM, Riddle MJ (2003) Missing and needed: polar marine ecotoxicology. Mar Pollut Bull 46:927-928

Clarke KR (1993) Non-parametric multivariate analyses of changes in community structure. Aust J Ecol 18:117-143

Conlan KE, Kim SL, Lenihan HS, Oliver JS (2004) Benthic changes during 10 years of organic enrichment by McMurdo Station, Antarctica. Mar Pollut Bull 49:43-60

Connell SD (2001) Urban structures as marine habitats: an experimental comparison of the composition and abundance of subtidal epibiota among pilings, pontoons and rocky reefs. Mar Environ Res 52:115-125

Davis AR, Butler AJ, van Altena I (1991) Settlement behaviour of ascidian larvae: preliminary evidence for inhibition by sponge allelochemicals. Mar Ecol Prog Ser 72:117-123

> Dayton PK (1989) Interdecadal variation in an Antarctic sponge and its predators from oceanographic climate shifts. Science 245:1484-1486

Deprez PP, Arens M, Locher H (1999) Identification and preliminary assessment of contaminated sites at Casey Station, Wilkes Land, Antarctica. Polar Rec 35:299-316

> Dobretsov S, Dahms HU, Qian PY (2004) Antilarval and antimicrobial activity of waterborne metabolites of the sponge Callyspongia (Euplacella) pulvinata: evidence of allelopathy. Mar Ecol Prog Ser 271:133-146

> Ellis D (1985) Taxonomic sufficiency in pollution assessment. Mar Pollut Bull 16:459

> Glasby TM (1997) Analysing data from post-impact studies using asymmetrical analyses of variance: a case study of epibiota on marinas. Aust J Ecol 22:448-459

Glasby TM (1998) Estimating spatial variability in developing assemblages of epibiota on subtidal substrata. J Mar Freshw Res 49:429-437

Glasby TM (2001) Development of sessile marine assemblages on fixed versus moving substrata. Mar Ecol Prog Ser 215:37-47

> Glasby TM, Connell SD (2001) Orientation and position of substrata have large effects on epibiotic assemblages. Mar Ecol Prog Ser 214:127-135

Goldberg ED, Beynon KI, de Groot AJ, Duinker JC and others (1975) Entry, distribution and fate of heavy metals and organohalogens in the physical environment. In: McIntyre $\mathrm{AD}$, Mills CF (eds) Ecological toxicology research. Plenum Press, New York, p 233-256

Green G, Nichols PD (1995) Hydrocarbons and sterols in marine sediments and soils at Davis Station, Antarctica: a survey for human derived contaminants. Antarct Sci 7: $137-144$

- Hansen IV, Weeks JM, Depledge MH (1995) Accumulation of copper, zinc, cadmium and chromium by the marine sponge Halichondria panicea Pallas and the implications for biomonitoring. Mar Pollut Bull 31:133-138 
Henry V, Bussers JC, Bouquegneau JM, Thomé JP (1990) Heavy metal and PCB contamination of Bryozoan colonies in the River Meuse (Belgium). Hydrobiologia 202:147-152

Keough MJ (1983) Patterns of recruitment of sessile invertebrates in two subtidal habitats. J Exp Mar Biol Ecol 66: $213-245$

Lenihan HS (1992) Benthic marine pollution around McMurdo Station, Antarctica: a summary of findings. Mar Pollut Bull 25:318-323

Lenihan HS, Oliver JS (1995) Anthropogenic and natural disturbances to marine benthic communities in Antarctica. Ecol Appl 5:311-326

Lenihan HS, Peterson CH, Kim SL, Conlan KE and others (2003) Variation in marine benthic community composition allows discrimination of multiple stressors. Mar Ecol Prog Ser 261:63-73

Maldonado M, Young C (1999) Effects of the duration of larval life on postlarval stages of the demosponge. J Exp Mar Biol Ecol 232:9-21

Marcano L, Nusetti O, Rodriquez-Grau J, Vilas J (1996) Uptake and depuration of copper and zinc in relation to metal-binding protein in the polychaete Eurythoe complacata. Comp Biochem Physiol 114:179-184

Morris CE, George J, Tate PM, Cathers B (2000) Impacts of wastewater discharge to the Antarctic marine environment. In: Hughson T, Ruckstuhl C (eds) Proc Sixth International Symp Cold Region Development. ISCORD, Hobart, p 155-158

Morrisey DJ, Howitt L, Underwood AJ, Stark JS (1992) Spatial variation in soft sediment benthos. Mar Ecol Prog Ser 81: 197-204

Muricy G (1991) Structure of sponge communities around the sewage out-fall at Cortiou (Marseille, France). Vie Milieu 41:205-221

Ng TYT, Keough MJ (2003) Delayed effects of larval exposure to $\mathrm{Cu}$ in the bryozoan Watersipora subtorquata. Mar Ecol Prog Ser 257:77-85

Oliver JS, Slattery PN (1985) Effects of crustacean predators on species composition and population structure of softbodied infauna from McMurdo Sound, Antarctica. Ophelia 24:155-175

Olsgard F, Somerfield PJ, Carr MR (1998) Relationships between taxonomic resolution, macrobenthic community patterns and disturbance. Mar Ecol Prog Ser 172:25-36

Pansini M, Pronzato R (1975) Preliminary analysis on the distribution of Porifera in areas exposed to different types of Pollution. Boll Mus Ist Biol Univ Genova 43:21-32

Patel B, Balani M, Patel S (1985) Sponge 'sentinel' of heavy metals. Sci Total Environ 41:143-152

Pearson TH, Rosenberg R (1978) Macrobenthic succession in relation to organic enrichment and pollution of the marine environment. Oceanogr Mar Biol Annu Rev 16:229-311

Quinn GP, Keough MJ (2002) Experimental design and data analysis for biologists. Cambridge University Press, Cambridge

Rauschert M (1991) Ergebrnisse der faunistischen Arbeiten im Benthal von King George Island (Südshetlandinseln,

Editorial responsibility: Hans-Heinrich Janssen, Oldendorf/Luhe, Germany
Antarctis). Ber Polarforsch 76:1-75

Rice WR (1989) Analyzing tables of statistical tests. Evolution 43:223-225

Snape I, Riddle MJ, Stark JS, Cole CM, King CK, Duquesne S, Gore DB (2001) Management and remediation of contaminated sites at Casey Station, Antarctica. Polar Rec 37: 199-214

Somerfield PJ, Clarke KR (1995) Taxonomic levels, in marine community studies, revisited. Mar Ecol Prog Ser 127: 113-119

Stachowicz JJ, Fried H, Osman RW, Whitlatch RB (2002) Biodiversity, invasion resistance and marine ecosystem function: reconciling pattern and process. Ecology 83: 2575-2590

Stanwell-Smith D, Barnes DKA (1997) Benthic community development in Antarctica: recruitment and growth on settlement panels at Signy Island. J Exp Mar Biol Ecol 212:61-79

Stark JS, Riddle MJ, Simpson RD (2003a) Human impacts in soft-sediment assemblages at Casey Station, East Antarctica: spatial variation, taxonomic resolution and data transformation. Austral Ecol 28:287-304

> Stark JS, Riddle MJ, Snape I, Scouller RC (2003b) Human impacts in Antarctic marine soft-sediment assemblages: correlations between multivariate biological patterns and environmental variables. Estuar Coast Shelf Sci 56: $717-734$

Stark JS, Riddle MJ, Smith SDA (2004) Influence of an Antarctic waste dump on recruitment to near-shore marine soft-sediment assemblages. Mar Ecol Prog Ser 276: $53-70$

Stark JS, Snape I, Riddle MJ, Stark SC (2005) Constraints on spatial variability in soft-sediment communities affected by contamination from an Antarctic waste disposal site. Mar Pollut Bull 50:276-290

Terlizzi A, Fraschetti S, Guidetti P, Boero F (2002) The effects of sewage discharge on shallow hard substrate sessile assemblages. Mar Pollut Bull 44:542-548

Underwood AJ (1981) Techniques of analysis of variance in experimental marine biology and ecology. Oceanogr Mar Biol Annu Rev 19:513-605

Underwood AJ (1993) The mechanics of spatially replicated sampling programmes to detect environmental impacts in a variable world. Aust J Ecol 18:96-116

> Underwood AJ, Chapman MC, Connell SD (2000) Observations in ecology: You can't make progress on processes without understanding the patterns. J Exp Mar Biol Ecol 250:97-115

Warwick RM (1988) The level of taxonomic discrimination required to detect pollution effects on marine benthic communities. Mar Pollut Bull 19:259-268

> Warwick RM (1993) Environmental impact studies on marine communities: pragmatical considerations. Aust J Ecol 18: $63-80$

- Wisely B, Blick A (1967) Mortality of marine invertebrate larvae in mercury, copper, and zinc solutions. Aust J Mar Freshw Res 18:63-72

Submitted: August 3, 2007; Accepted: April 30, 2008

Proofs received from author(s): July 17, 2008 